\title{
KNOWLEDGE OF BREASTFEEDING TECHNIQUES AMONG PRIM GRAVID WOMEN
}

\author{
Sriyatin $^{1}$, Ninda Lutfiani ${ }^{2}$ \\ Department of Nursing, Polytechnic Kemenkes Tasikmalaya, Program Study of Nursing, Cirebon \\ Correspondence: atinsriyatin@yahoo.co.id
}

\begin{abstract}
The Indonesian health research data (Riskesdas) in 2010 showed that the percentage of mothers who breastfeed their baby were low especially Exclusive Breastfeeding. The percentage of infants who get exclusive breastfeeding was only $15.3 \%$. Factors that affect mothers not giving breast milk to their babies include limited knowledge about the benefits of breast milk and breastfeed techniques. Bojonggebang village had the lowest coverage of exclusive breastfeeding in Babakan District in 2015. The purpose of this study was to determine the level of knowledge of primipara women about breastfeeding techniques. This research was a descriptive quantitative study. The number of samples was 40 post-partum women who selected by the total sampling technique. The sample criteria were prim gravid women, breastfeed their baby, living in the village of Bojonggebang, and willing to become respondents. Data collection was conducted from May 30 to June 4, 2016 using a questionnaire containing data on maternal demographics, and knowledge about breastfeeding techniques. The results showed that the majority of respondent were 20-34 years old (97.5\%), and had basic education (65.0\%). Most mothers have limited knowledge of breastfeeding techniques (82.5\%). There were women who had a baby before 20 years old, and most women who participated in this study only attending the basic education. These two characteristics increase the health risks of women and their babies. Health education, and counseling programs are needed for prim gravid women to support their health.
\end{abstract}

Keywords: breastfeeding techniques, knowledge, prim gravid

\section{INTRODUCTION}

Breastfeeding has a very important role for infants' nutrition, immunity, and protect baby from various diseases. According to the Indonesian basic health research data (Riskesdas) in 2010, the breastfeeding target in Indonesia had low achievement. The percentage of babies who get exclusive breastfeeding (only breastmilk for 6 months) was $15.3 \%$. This is probably due to lack of awareness of women, family, and community related to the importance of exclusive breastfeeding for babies so that they do not support breastfeed women optimally.

The low percentage of breastfeeding achievement can be caused by various factors including maternal, infant, and environmental factors. Maternal factors include low knowledge about ASI (benefits, how to breastfeed), no program counseling, socio-culture related to breastfeeding, working mothers, and lack of motivation to breastfeed (Kementerian Kesehatan Republik Indonesia, 2008). For babies, receiving exclusive breastfeeding is very important for their health and life, so the government established a regulation namely 
Sriyatin : Knowledge of Breastfeeding Techniques among Prim Gravid Women

Kepmenkes RI No. 450 / MENKES / IV / 2004 concerning the provision of breast milk exclusively for Indonesian babies.

Ineffective breastfeeding techniques may cause several problems to mothers and babies including nipple blisters, swollen breasts, blocked ducts of breast milk, mastitis, breast abscesses, breast milk does not come out optimally, and finally breastmilk production decreases. The impact on the baby includes the milk does meet baby's need, don't want to breastfeed, and getting health issues. The problem of the nipples, one of causes is the position and attachment of the baby to mother's breast. This problem can be overcome by improving the position and attachment of the baby to the breast. In the case of nipple and areola abrasions and fissures, pain can be reduced by improving the appropriate position of the baby (Rahayu, 2012).

The success of breastfeeding and problems in breastfeeding are related to the appropriate breastfeeding technique (Soetjiningsih, 2012). According to data from the West Java Health Office in 2013, the rate of exclusive breastfeeding in West Java was low (36\%). While the rate of length of breastfeeding up to three months old babies reached $78 \%$. Siti Muliawati (2011) study's found that 20 out of 37 respondents (54\%) carried out a single breastfeeding technique and the results showed that breastfeeding was not optimal, because the majority of mothers were young, first child, and lack of knowledge or information about breastfeeding techniques.

In 2015 the Bojonggebang village had the lowest coverage of exclusive breastfeeding in Babakan sub-district. Based on the results of a preliminary study that conducted in November 2015 found $3(30 \%)$ of 10 primipara mothers did not have any breastfeeding problems and 7 people (70\%) did not know about the appropiate breastfeeding technique. Based on the description above, the researchers were interested in conducting research 
"Knowledge of Prim gravida's mother about breastfeeding techniques in the Village of Bojonggebang, Babakan District.

\section{METHODS}

The design of this study was the descriptive quantitative. The population in this study was all primiparous mothers who breastfed in Bojonggebang village, there were 40 women, and then became the study sample. Researchers asked respondents to fill out questionnaires about breastfeeding techniques. Univariate analysis used in the form of percentages and frequency tables. This study described the knowledge of primipara mothers in breastfeeding.

\section{RESULTS}

\section{Characteristic of respondents}

Table 1.Characteristic of Respondents $(n=40)$

\begin{tabular}{lcc}
\hline \multicolumn{1}{c}{ Component } & Frequency (n) & $\begin{array}{c}\text { Percentage } \\
(\%)\end{array}$ \\
\hline Age & 1 & \\
$<20$ or $>35$ (High Risk) & 39 & 2,5 \\
20-35 (Low Risk) & & 97,5 \\
& & \\
Education & 26 & \\
Elementary & 11 & 65,0 \\
Middle & 3 & 27,5 \\
High & & 7,5 \\
\hline
\end{tabular}

Table 1 shows that the majority of respondents in the healthy reproductive age category were $20-35$ years $(97.5 \%)$. Data also shows that the majority of respondents attended basic education $(65.0 \%)$.

\section{The Level of Knowledge}

The level of respondents' knowledge about breastfeeding techniques is presented in table 2 
Sriyatin : Knowledge of Breastfeeding Techniques among Prim Gravid Women

Table 2. Level of Knowledge about Breastfeeding Techniques

\begin{tabular}{|c|c|c|}
\hline Level of Knowledge & $\begin{array}{l}\text { Frequency } \\
\text { (n) }\end{array}$ & Percentage (\%) \\
\hline Good & 7 & 17,5 \\
\hline Moderate & 33 & 82,5 \\
\hline Insufficient & 0 & 0,0 \\
\hline Total & 40 & 100 \\
\hline
\end{tabular}

Table 2 shows that most respondents had a moderate level of knowledge about breastfeeding techniques $(82.5 \%)$.

\section{DISCUSSION}

Factors that influence knowledge include age, education, information / media, experience, social, cultural and economic, as well as the environment. The researcher found the majority of respondents were 20-35 years old (97.5\%) or reproductive healthy age. The reproductive period of women was divided into 3 periods, namely young reproduction (15-19 years), healthy reproduction (20-35 years), and older reproduction (> 35 years old). During a healthy reproductive age women have physical, mental and emotional readiness that can affect to the success of breastfeeding process. The researchers also found that $2.5 \%$ of respondents aged $<20$ and $>35$ years old were high risk categories. Age $<20$ years causes a lack of knowledge about reproductive health and is physically immature. The government developed the Youth Health Program, to prevent pregnant adolescents age $<20$ years old.

The second factor that might influence knowledge is a history of formal education. The majority of respondents attended primary education (65.0\%). The level of formal education might influence women's behavior in accessing information and getting correct information including information on breastfeeding techniques. This is in line with Amalia's (2014) study, found that a low level of maternal education will have an impact on maternal behavior in dealing with problems including breastfeeding. The researchers also found $27.5 \%$ of respondents had secondary education and $7.5 \%$ with highly educated. It is expected that 
Sriyatin : Knowledge of Breastfeeding Techniques among Prim Gravid Women

higher education will increase curiosity about breastfeeding techniques and the benefits of Exclusive Breastfeeding. However, it does not mean that women with low formal education knowledge always has a limited understanding of health as the source of health knowledge varies. Sources of health knowledge include health workers, the media, and families.

The results of the analysis show that most of the respondents' knowledge $(82.5 \%)$ is moderate. Inadequate levels may be due to lack of experience. Women with children more than one may have different experiences with prim gravid women. Prim gravid women are at the stage of seeking information including how to take care their babies including breastfeed them (Varney, 2006). Mother's knowledge of breastfeeding techniques needs to be improved by finding information about the benefits and techniques of breastfeeding. Valid sources of information are health workers and other reliable media such as books or leaflets in health services. The results of this study were different from the Tringganu's (2013) study which showed that most prim gravid women $(59.5 \%)$ in their studies had less knowledge related to breastfeeding techniques. Less knowledge is caused by various things such as lack of experience, lack of information, or lack of desire to find information.

\section{CONCLUSION}

This research shows that there are still women who give birth before the age of 20 and most women only complete basic education. The characteristics of respondents in this study might increase the health risks of women and their babies. Health education, counseling and counseling programs are needed for prim gravid women to support the health of women and their babies so that they can prevent various health problems that might threaten health. 
Sriyatin : Knowledge of Breastfeeding Techniques among Prim Gravid Women

\section{REFERENCES}

Anik Maryunani. (2012). Inisiasi Menyusu Dini, ASI Eksklusif dan Manajemen Laktasi. Jakarta: TIM.

Arikunto. S. (2006). Prosedur Penelitian : suatu pendekatan praktik. Jakarta: Rineka Cipta.

Astuti, M. (2010). Buku Pintar Kehamilan. Jakarta : EGC.

Atikah Proverawati, Eni Rahmawati. (2010). Kapita Selekta ASI \& Menyusui. Yogyakarta: Nuha Medika.

Azwar, Saefuddin. (2007). Metode Penelitian. Yogyakarta : Pustaka Pelajar.

BKKBN. (2006). Deteksi dini komplikasi persalinan. Jakarta: BKKBN.

Budiman \& Agus Riyanto. (2013). Kapita Selekta Kuesioner (Pengetahuan dan Sikap dalam Penelitian Kesehatan). Jakarta: Salemba Medika.

Gklinis. (2006). Setiap Tahun 30 Ribu Anak dapat diselamatkan dengan Pemberian ASI.

Diakses pada tanggal 17 Oktober 2015 dari http://www.mediaindonesia.com.

Herlina. (2009). Pendekatan Praktis Metodolog Riset Keperawatan. Jakarta: Salemba Medika.

Hidayat, Aziz Alimul. (2007). Metode Penelitian Keperawatan dan Analisis Data. Jakarta: Salemba Medika.

Kelly, Paula. (2010). Buku Saku Asuhan Neonatus \& Bayi. Jakarta: EGC.

Manuaba. (2008). Ilmu Kebidanan, Kandungan dan KB, Jakarta: EGC.

Muliawati, S. (2011). Studi Deskriptif Pelaksanaan Teknik Menyusui Bayi Tunggal. Diakses pada tanggal 17 Oktober 2015 dari http://www.apikescm.ac.id.

Prawirohardjo, Sarwono. (2009). Ilmu Kebidanan. Jakarta: Penerbit Yayasan Bina Pustaka.

Rachmawati \& Kuntari. (2007). ASI Eksklusif Demi Sang Anak. Diakses pada tanggal 17 Oktober 2015 dari http://tamanfirdaus.multiply.com/reviews/item/7.html.

Ramaiah, S. (2007). ASI dan Menyusui. Jakarta: PT. Bhuana Ilmu Populer. 
Sriyatin : Knowledge of Breastfeeding Techniques among Prim Gravid Women

Soetjiiningsih. (2013). ASI: Petunjuk untuk Tenaga Kesehatan. Jakarta: EGC.

Suherni. (2009). Perawatan Masa Nifas. Yogyakarta: Fitramaya.

Sulistianingsih, R. (2012). Tingkat Pengetahuan Ibu Menyusui Tentang Cara Menyusui yang Benar. Diakses pada tanggal 17 Oktober 2015 dari http://digilib.stikeskusumahusada.ac.id.

Syafrudin, dkk. (2011). Untaian Materi Penyuluhan KIA (kesehatan Ibu dan Anak). Jakarta: Trans Info Media.

Utami Roesli. (2008). Inisiasi Menyusu Dini. Jakarta: Pustaka Bunda.

UU RI. (2008). Undang-Undang Republik Indonesia No. 11 Tahun 2008 Tentang Teknologi Komunikasi Dan Informasi. Diakses pada tanggal 17 Oktober 2015 dari http://bti.unpar.ac.id/undang-undang/ite/

Varney. (2006). Buku Ajar Asuhan Kebidanan. Jakarta: EGC.

Wasis. (2008). Pedoman Riset Praktis untuk Profesi Perawat. Jakarta: EGC.

Weni Kristiyanasari. (2009). ASI, Menyusui \& SADARI. Yogyakarta: Nuha Medika. 